\title{
Seismic analysis of the Ignalina NPP downcomers pipes
}

\author{
G. Dundulis \& E. Uspuras \\ Lithuanian Energy Institute, Lithuania
}

\begin{abstract}
The Ignalina NPP located in Lithuania, close to the borders of Belarus and Latvia. The Baltic region is considered as an aseismic or of very low seismic activity. However, the Ignalina NPP is in the area of the East-European platform, at the junction of two large structure elements: the Baltic sineclize and the Mazur-Belarus antiklize. Therefore, the crystal foundation and sediment case are separated by a series of tectonic breaks. From the evidence of the tectonic disintegration of this area, the probability of availability of tectonic disintegration zones near the Ignalina NPP is relatively larger compared to the neighbour regions. According this the seismic assessment of the Ignalina NPP is important.

The seismic assessment of the downcomers pipes is presented in the paper. The analysis was carried out according to code ASME III, division I, subsection NC. The finite element method was used for the present analysis. The envelopes of floor response spectrum were used for seismic analysis. The stresses of the pipes were examined. The results of the seismic analysis confirmed that downcomers pipes fulfil the ASME requirements.
\end{abstract}

Keywords: nuclear power plant, seismic analysis, finite element method, floor response spectra, stress analysis.

\section{Introduction}

The Ignalina NPP operates a RBMK (Chanelized Large Power Reactor) type reactor. Disadvantage of this reactor is extremely complex design of the buildings and piping systems with respect to those built in Western countries. The graphite structure consists of 2488 channels, made up of columns of bricks each with an axial hole for the channel tube [2]. These channels are welded to the 
pipes of the main circulation circuit. Main circulation circuit consists of two loops, components of which are arranged symmetrically with respect to the vertical axis of the reactor. The main circulation circuit piping is produced from austenitic stainless steel 08X18H10T. The outside diameter of piping is $325 \mathrm{~mm}$, the wall thickness $-16 \mathrm{~mm}$. At normal operation conditions the internal pressure is 6.9-8.4 $\mathrm{MPa}$ and the temperature of coolant is $260-270^{\circ} \mathrm{C}$ [2]. One loop of Ignalina NPP main circulation circuit austenitic piping is shown in fig.1.

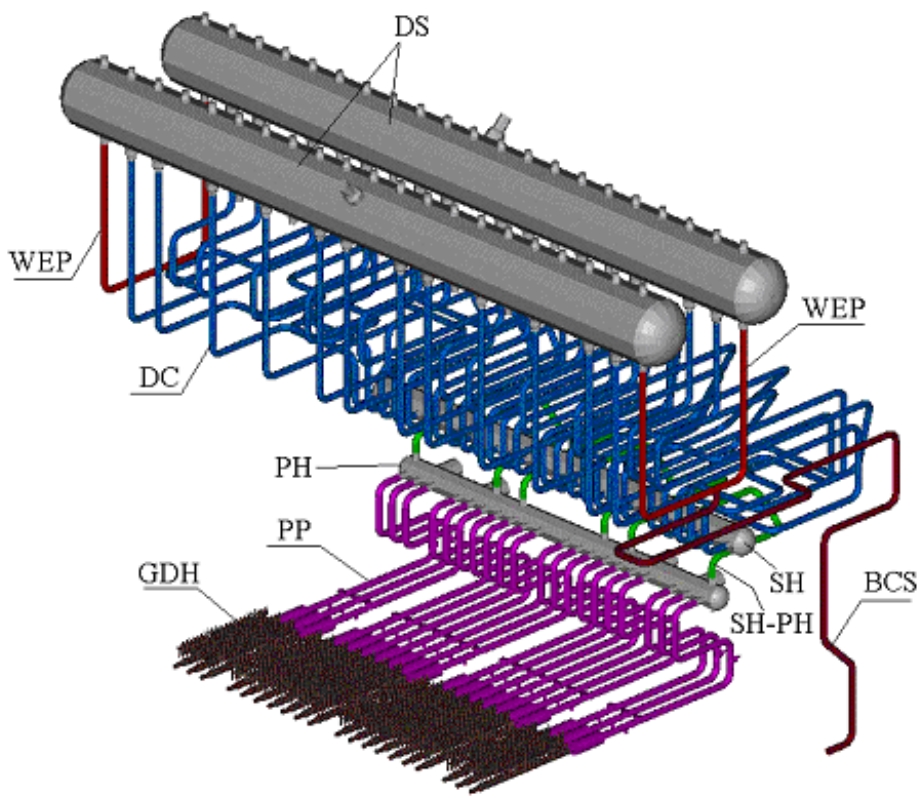

Figure 1: $\quad$ Main circulation circuit austenitic piping of one loop (WEP water equalizing piping; DC - downcomers; $\mathrm{SH}-\mathrm{PH}$ - bypass between suction header $(\mathrm{SH})$ and pressure header $(\mathrm{PH})$; PP pressure piping, connecting pressure header $(\mathrm{PH})$ and group distribution header (GDH); GDH - group distribution headers; $\mathrm{BCS}$ - blowdown and cooldown system piping).

During in-service inspection cracks were detected in pipes of main circulation circuit. The cracking in Ignalina NPP main circulation circuit piping welds, produced from austenitic stainless steel of type 08X18H10T, is caused by intergranular stress corrosion cracking [3]. This type of cracks is very dangerous in case of seismic loading. The seismic analysis of the main circulation circuit was performed. The seismic analysis of the downcomers pipes is presented in the paper. According the recommendation of requirements [4], the most suitable and reliable numerical technique should be used for structures, systems and components of nuclear facilities in order to minimize the contribution of the modelling techniques used for the uncertainties in the results. Three dimensional 
detailed finite element models, presenting the most accurate modelling technique, are basically recommended. For this reason an accurate and detailed three-dimensional finite element model was considered for the seismic analysis of downcomer pipes. The envelopes of floor response spectrum were used for the seismic analysis. The evaluation of the strength of the downcomer pipes was performed. The analysis was carried out according to code ASME III, division I, subsection NC.

\section{Methodology of the seismic analysis}

The finite element method was used for the seismic analysis of the pipes. A validated finite element code ALGOR/PIPEPLUS is used for numerical simulation [5].

The multimodal analysis of response spectrum is carried out under the following basic assumptions:

1. The pipeline was analysed as linear beam system;

2. The fastening of pipelines through walls were accepted as rigid support (the longitudinal displacement are possible only);

3. The modal analysis was carried out up to frequency $33 \mathrm{~Hz}$ (on occasion range was reduced up to acceptable);

4. The following combination methods were used:

- Inter - modal combination - method elimination of close spaced frequencies;

- Inter - spatial combination - square root of sum of square;

- Inter - foundation combination - the direct sum (the method assumes that the support excitations in a given direction can be considered to be all in phase).

5. The envelopes of floor response spectrum were used;

6. The possible changes of distance between rigid support were not considered in the analysis;

7. The analysis was carried out according to code ASME III, division I, subsection NC.

According to code ASME III, division I, subsection NC for pipes the effects of pressure, weight, other sustained loads, and occasional loads, including nonreversing dynamic loads (seismic loads) must meet the requirements [6]:

$$
S_{0}=B_{1} \frac{P_{\max } D_{0}}{t_{n}}+B_{2}\left(\frac{M_{A}+M_{B}}{Z}\right) \leq 1.8 S_{h}
$$

$\mathrm{B}_{1}, \mathrm{~B}_{2}$ - primary stress indices, $\mathrm{P}_{\max }-$ peak pressure, $\mathrm{D}_{0}$ - outside diameter of pipes, $t_{h}-$ nominal wall thickness, $M_{A}-$ resultant moment loading on cross section due to weight and other sustained loads, $\mathrm{M}_{\mathrm{B}}$ - resultant moment loading on cross section due to nonreversing dynamic loads, $\mathrm{Z}$ - section modulus of pipes, $S_{h}$ - material allowable stress at temperature consistent with the loading under consideration. 


\section{Floor response spectrum of INPP}

Knowledge of the seismic activity of Lithuania and adjacent countries is based mainly on historical records [7, 8]. Scandinavian seismic networks, and a few available Baltic seismic stations provide only scarce information, the consistency of which is debated [9]. Based on these data, the maximum seismic potential of the Baltic region is estimated at no less than $\mathrm{ML}_{\mathrm{L}}=5.0, \mathrm{I}_{\mathrm{o}}=7$, the average focal depth being about $10 \mathrm{~km}$.

The Russian Design and Scientific-Research Institute for Complex Energetic Technology (VNIEPET, Saint-Petersburg) carried out analysis of the floor response spectra for Ignalina NPP [10]. The Maximal Credible Earthquake was assumed $\mathrm{IMCE}_{\mathrm{MCE}}=6.5$ and the maximal acceleration of soil were assumed $75 \mathrm{~cm} / \mathrm{sec}^{2}$. The floor response spectra was calculated using a simplified "stick" one-dimensional column discrete-mass model taking into account the elastic deformations of foundation [11]. A whole structure at the level of elastic spring support has all 6 degrees of freedom, while at the level of each floor mechanical behaviour is restricted by 4 degrees of freedom (translation displacement into axial $x, y$, and $z$ and rotation around axis $z$ ). The response spectra were calculated in the level, where are supports of main equipment of the reactor. The support points of different equipment of the NPP are presented in fig. 2.

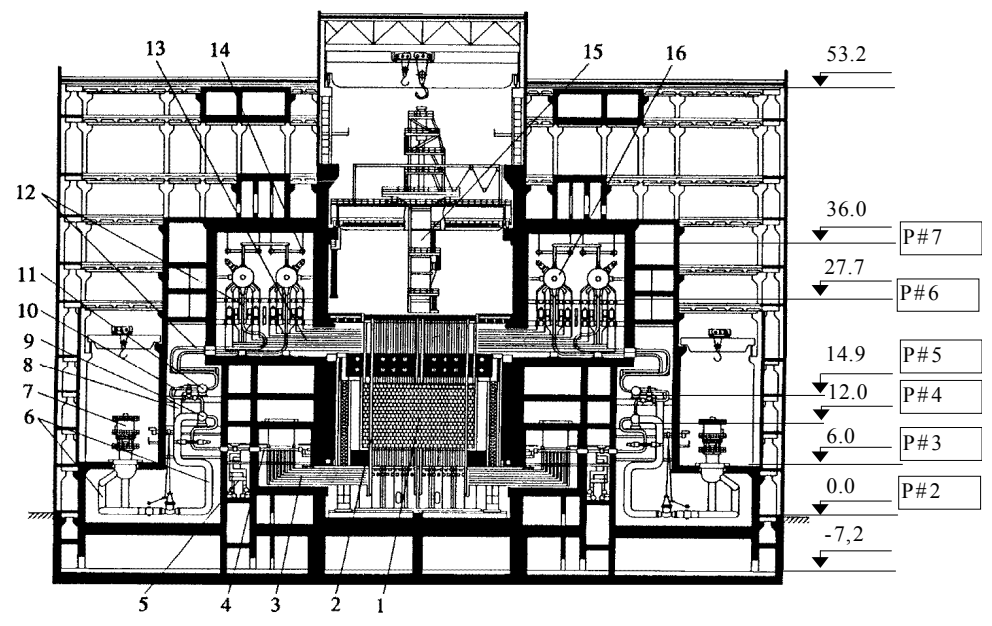

Figure 2: Cross-section of the reactor building with main components 1 - graphite stack, 2 - fuel channel feeder pipes, 3 - water pipes, 4 - group distribution header, 5 - emergency core cooling pipes, 6 - pressure pipes, 7 - main circulation pump, 8 - suction pipes, 9 - pressure header, 10 - bypass pipes, 11 - suction header, 12 - downcomers, 13 - steam and water pipes, 14 - steam pipes, 15 - refueling machine, 16 - separator drum.

Vertical and two horizontal (for East-West and North-South directions) floor response spectra are calculated. Calculation results for East-West direction are 


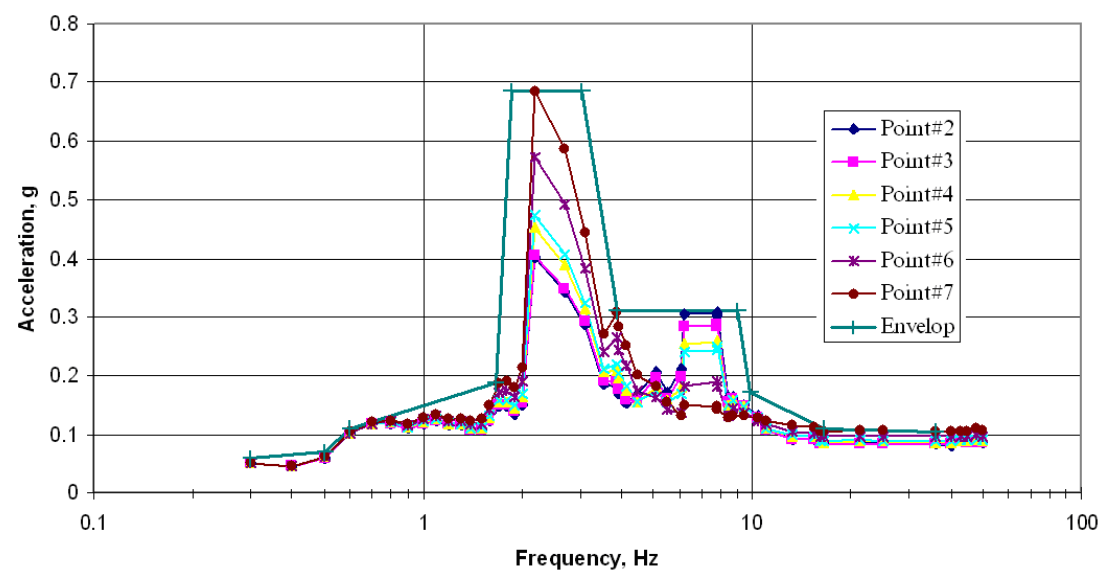

Figure 3: The response spectrum in $\mathrm{x}$ direction.

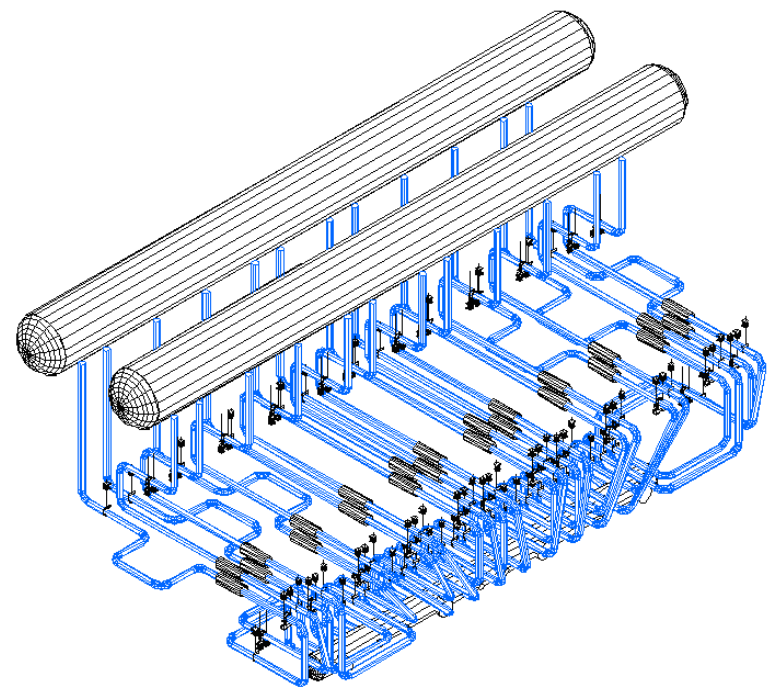

Figure 4: General view of downcomers with drum separator and section header.

presented in fig. 3. The envelopes of floor response spectrum were calculated and were used for the seismic analysis of the downcomer pipes.

\section{The finite element model of the downcomers}

The downcomers pipes direct the water from the drums separator to the section header of the main circulation pumps. Each drum separator is connected to the 
section header by 12 downcomers pipes $\left(325^{*} 16 \mathrm{~mm}\right)$. The geometry of the downcomers pipes with drum separator and suction header are presented in fig. 4. The supports of the pipes are presented in this figure.

FE model prepared for seismic analysis is presented in fig. 5. The weight of the drum separator, stem pipes located in drum separator compartment and suction header are involved in the FE model of downcomers pipes. The anchor elements were used for modelling the supports of the drum separator and suction header. The spring elements were used for modelling the supports of the downcomers. The mounting tightness of the pipes is evaluated in this model. The pressure of normal operation in the drum separator, downcomers and suction header are evaluated in the FE model.

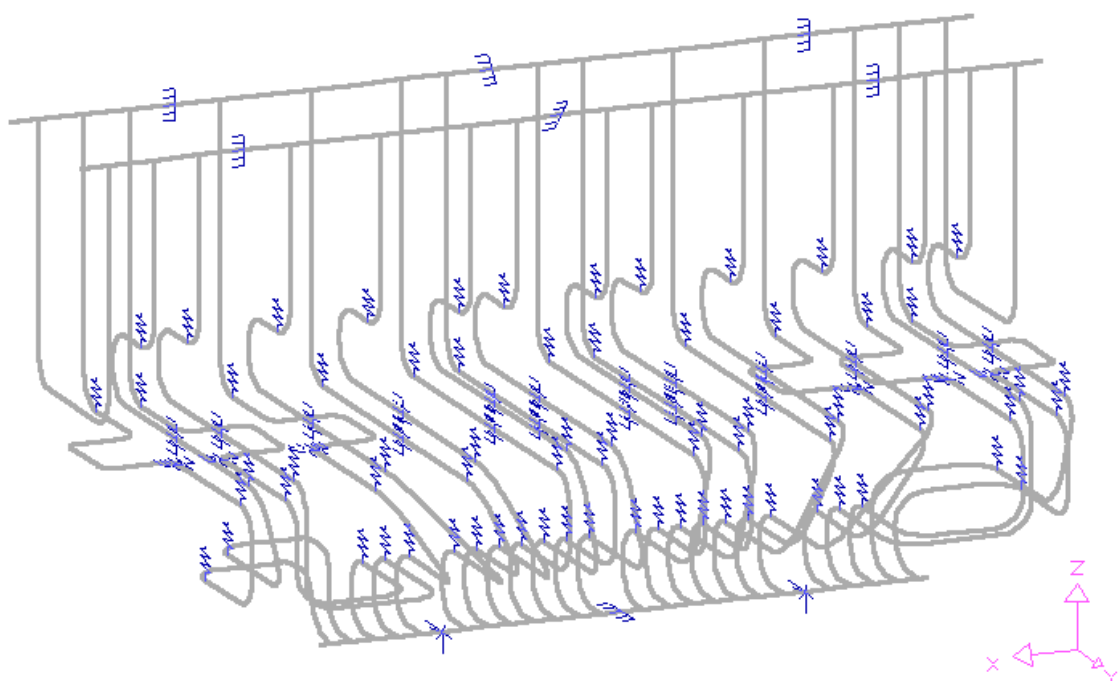

Figure 5: $\quad$ FE model of DC for seismic analysis.

The downcomers are produced from austenitic stainless steel 08X18H10T. The mechanical properties of this steel are presented in Table 1.

Table 1: $\quad$ The mechanical properties of austenitic stainless steel 08X18H10T and operational loads of the downcomers.

\begin{tabular}{|c|c|c|c|c|c|}
\hline $\begin{array}{c}\text { Tensile } \\
\text { strength at } \\
285^{0} \mathrm{C}\end{array}$ & $\begin{array}{c}\text { Yield stress at } \\
285^{0} \mathrm{C}\end{array}$ & $\begin{array}{c}\text { Elastic } \\
\text { modulus }\end{array}$ & Density & Pressure & $\begin{array}{c}\text { Temper } \\
\text { ature }\end{array}$ \\
\hline$R_{m}^{T}$ & $R_{p 0.2}^{T}$ & $\mathrm{E}$ & $\rho$ & $\mathrm{p}$ & $\mathrm{T}$ \\
\hline $\mathrm{MPa}$ & $\mathrm{MPa}$ & $\mathrm{GPa}$ & $\mathrm{kg} / \mathrm{m}^{3}$ & $\mathrm{MPa}$ & ${ }^{\circ} \mathrm{C}$ \\
\hline 412 & 177 & 180 & 7800 & 7.1 & 285 \\
\hline
\end{tabular}




\section{Results and discussion}

The seismic analysis of the downcomers was performed according to code ASME III, division I, subsection NC for pipes. The effects of pressure, weight, mounting tightness and seismic loads was evaluated in this analysis. The analysis results of downcomers pipes displacement and stresses distribution are presented in figures 6 and 7.

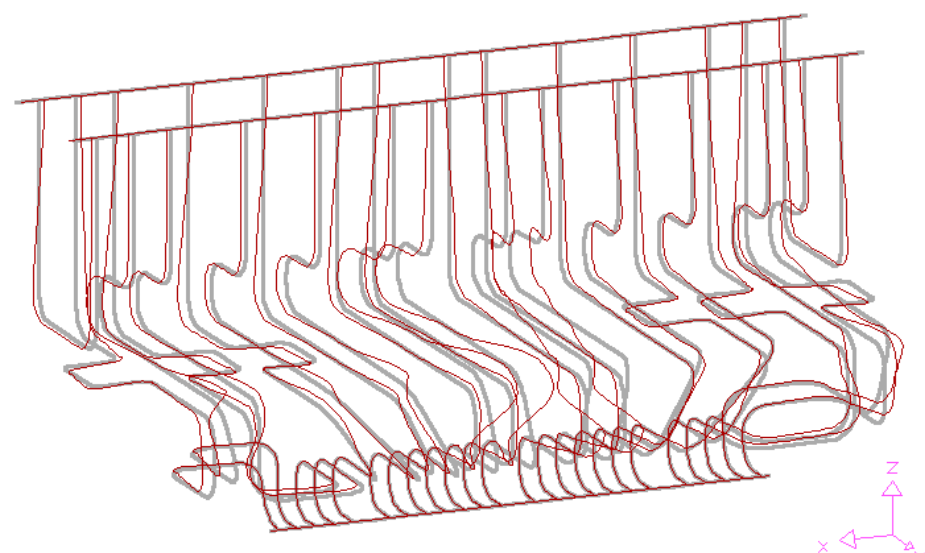

Figure 6: Calculated displacements of the downcomers pipes.

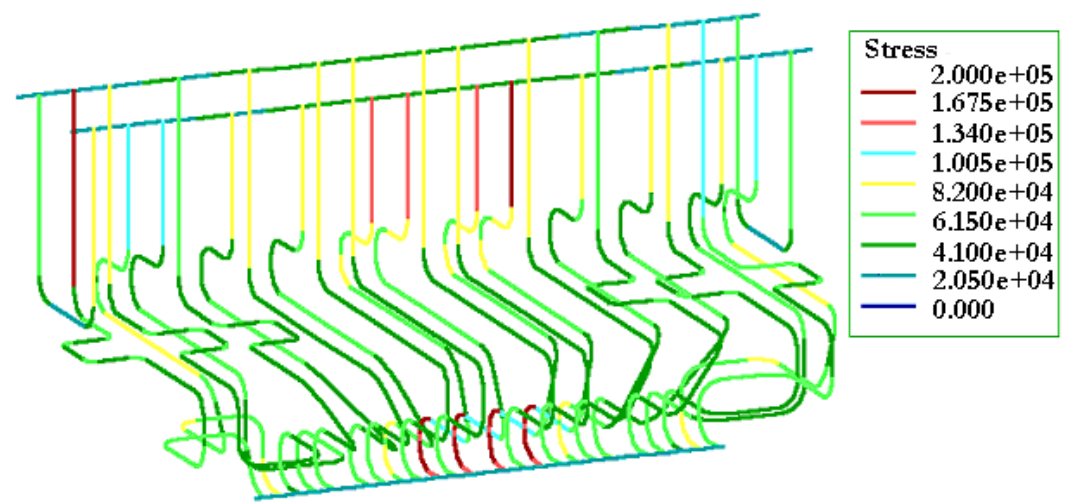

Figure 7: Distribution of stresses in the downcomer pipes.

Calculated maximal displacements of the pipes are:

- in direction of axis $\mathrm{x}-153.6 \mathrm{~mm}$;

- in direction of axis $\mathrm{y}-41.5 \mathrm{~mm}$;

- in direction of axis $\mathrm{z}-38.8 \mathrm{~mm}$

Calculated maximal stresses of the pipes are the following:

- Radial stress - 74.1 MPa;

- Axial stress - 151.6 MPa;

- According ASME III - 164.0 MPa. 
Results of the structural calculations reveal that in case of the seismic event (dead weight + inner pressure + mounting tightness + seismic loads) the maximum ratio of load in downcomers is about 0.7 , i.e. less than 1 . Therefore, structural integrity of the pipes, following the seismic loads, will be violated.

\section{Concluding remarks}

The detailed 3D finite element model was applied for the seismic analysis of Ignalina NPP downcomers pipes. The analysis was carried out according to code ASME III, division I, subsection NC. The envelopes of floor response spectrum were used for seismic analysis. The results of the seismic analysis confirmed that downcomers pipes fulfil the ASME requirements.

\section{References}

[1] S. Sliaupa, R. Kacianauskas, D. Markauskas, G. Dundulis and E. Uspuras. Design Basis Earthquake of the Ignalina Nuclear Power Plant. Geology, 2 (54), pp. 19-30, 2006.

[2] Almenas, K., Kaliatka, A. and Uspuras, E., Ignalina RBMK-1500. A source Book, extended and updated version, Ignalina Safety Analysis Group, Lithuanian Energy Institute, 1998.

[3] Dundulis G., Nedzinskas L., Klimašauskas A. Ageing of austenitic pipes in Ignalina NPP // Proceed. of Intern. Symposium on Nuclear Power Plant Life Management, Book of Extended Synopses. Budapest, Hungary, 2002. p. 72-73.

[4] P-2006-01. General Requirements for Analysis of Seismic Impact on Nuclear Power Facilities. Vilnius: VATESI, 2007.

[5] ALGOR. PipePlus. Release notes. Algor, Inc, USA, 1996.

[6] Rules for Construction of Nuclear Power Plant Components. ASME Boiler and Pressure Vessel Code, Section III, Division 1, Subsection NC. New York, The American Society of Mechanical Engineers, 1995.

[7] Avotine, I., Boborikin A.M., Emelianov A.P., Sildvia N.N. 1988. Catalogue of the historical earthquakes in Belarus and Baltic countries. Seismological bulletin 1984. Minsk. 126-137 (in Russian).

[8] Ilginyte V. 1998. Seismic activity of Lithuania. Ph.D. dissertation. Vilnius. 127 p. (in Russian).

[9] Pacesa A. 2003. Seismological monitoring of Lithuania in 2002. Report. Vilnius. 47-49 (in Lithuanian).

[10] Report "Determination of floor acceleration and response spectra of Ignalina NPP buildings D and G in case earthquake loads", The Russian Design and Scientific-Research Institute for Complex Energetic Technology (VNIEPET, Saint-Petersburg), No. 91-10335, 1991 (in Russian).

[11] Popov, A.I., Application of computer codes in assessing the strength of structural components and equipment as part of the service life extension programme for Leningrad Units 1 and 2. Proc. Of the International Conference 'Pressure tube reactors: Problems and Solutions', Moscow, 19 October 2004, VNIPIET: Moscow, CD 8 p. (in Russian). 